\title{
Dokaz Eulerove formule u Zome sustavu
}

\author{
Anita Brozović, Sanja Rukavina
}

\section{Sažetak}

Zome Tool modeli predstavljaju sustav koji se može koristiti u nastavi matematike za izradu matematičkih struktura i bolje uočavanje i razumijevanje njihovih svojstava. U ovom članku opisujemo primjenu Zome modela pri dokazivanju Eulerove formule za poliedre kroz prikaz radionice koja je provedena u drugom razredu srednje škole.

Ključni pojmovi: Zome modeli, graf, poliedar, Eulerova formula

\section{Uvod}

Odjel za matematiku Sveučilišta u Rijeci bio je partner na ESF projektu Razvoj modernih studijskih programa za izobrazbu nastavnika informatike, tehnike, biologije, kemije, fizike i matematike na temeljima razvoja Hrvatskog kvalifikacijskog okvira čiji je nositelj bio Prirodoslovnomatematički fakultet Sveučilišta u Splitu. U okviru projekta nabavljena su i didaktička sredstva i pomagala kao potpora realizaciji razvijenih studijskih programa. Tako je nabavljen i set Zome Tool modela (http://www.zometool.com) za korištenje u edukaciji budućih nastavnika matematike. Više o karakteristikama Zome Tool modela može se naći u [1], 2], 3, 4 , [5, 6]], a u nastavku opisujemo radionicu koju je u okviru svog diplomskog rada na Diplomskom sveučilišnom studiju Matematika (smjer nastavnički) pod mentorstvom prof. dr. sc. Sanje Rukavina osmislila i primjenom Zome modela izvela Anita Brozović. 


\section{Radionica kao dio obrazovnog procesa}

Radionica Dokaz Eulerove formule u Zome sustavu namijenjena je za drugi razred srednje škole, a za njezino izvođenje potrebna su dva školska sata. Na početku radionice učenike se upoznaje s osnovnim pojmovima iz teorije grafova. Definiraju se graf, šetnja u grafu i ciklus te uvede pojam povezanosti. Zatim se navode primjeri cikličkih i acikličkih grafova te povezanih i nepovezanih grafova. Definira se pojam stabla koji se koristi tijekom cijele radionice, nakon čega slijede aktivnosti u kojima učenici trebaju izraditi ili prepoznati stablo. Iako navedene pojmove učenici ne susreću na redovnoj nastavi, njihovo korištenje pomaže u utvrđivanju pojmova koje učenici poznaju od ranije. Prilikom izrade stabla čiji vrhovi su vrhovi dodekaedra i stabla čiji vrhovi su vrhovi ikosaedra, učenici će obnoviti znanje o broju strana, vrhova i bridova dodekaedra i ikosaedra. Također će na konkretnim modelima primijeniti Eulerovu formulu za poliedre. Izradom isprepletenih stabala te dokazivanjem Eulerove formule, učenici će ponoviti i primijeniti definicije pravilnih poliedara, dualnih poliedara, konveksnih poliedara i konveksnih mnogokuta. Cilj radionice je pomoću Zome materijala, na jednostavan način, dokazati da za poliedre vrijedi Eulerova formula te obnoviti znanja o poliedrima.

\section{Tijek izvođenja radionice}

Materijali:

- Zome Tool modeli

- izrađeni modeli pravilnih ikosaedara duljina bridova $b_{2}$ i pravilnih dodekaedara duljina bridova $b_{1}$

- izrađeni modeli sa središtem pravilnog dodekaedara i ikosaedara

- izrađeni modeli kocaka i njihovih duala oktaedara

- PowerPoint prezentacija

Tema radionice je dokaz Eulerovog teorema za poliedre pomoću Zome materijala. Učenici će, koristeći Zome materijale, dokazati Eulerov teorem za poliedre radeći u grupama od po četvero. Radionica započinje upoznavanjem učenika sa Zome Tool modelima. Također, za daljnji tijek radionice, vrlo je važno upoznati ih s nekim pojmovima iz teorije grafova. Tijekom izvođenja radionice često će se susretati s pojmovima stablo i ciklus. Pri definiranju tih pojmova potrebno je definirati još neke matematičke pojmove iz teorije grafova, no pritom treba paziti da se ne koriste previše stručni izrazi i također da se definicije tih pojmova 
povežu sa Zome Tool modelima. Najprije je potrebno definirati što je graf. Dakle, graf je matematička struktura koja se sastoji od vrhova i bridova pri čemu svaki brid povezuje dva vrha koji se zovu krajevi brida. Nakon definicije grafa slijedi zorni prikaz nekog grafa izrađen $\mathrm{u}$ programu Geogebra. Zatim se objašnjava da je graf u Zome sustavu matematička struktura koja se dobije povezivanjem Zome loptica i štapića tako da svaki štapić s obje strane sadrži Zome lopticu. Zome loptice grafa se nazivaju vrhovi grafa, a štapići su bridovi grafa. Potom uvodimo pojam šetnje $u$ grafu. šetnja $u$ grafu je netrivijalan konačan niz $W=v_{0} e_{1} v_{1} \ldots e_{k} v_{k}$, pri čemu su $v_{0}, v_{1}, \ldots, v_{k}$ vrhovi, a $e_{1}, e_{2}, \ldots, e_{k}$ bridovi i vrijedi da brid $e_{i}$ sadrži vrhove $v_{i-1}$ i $v_{i}$. Bitno je napomenuti da vrhovi u šetnji ne moraju nužno biti svi različiti. Kako je učenicima pojam šetnje dosta apstraktan, taj pojam se može objasniti pomoću neke konkretne šetnju u nekom grafu. Također je potrebno definirati pojam zatvorene šetnje kako bi učenici mogli razumjeti definiciju ciklusa. šetnja $W=v_{0} e_{1} v_{1} \ldots e_{k} v_{k}$ je zatvorena ako je $v_{0}=v_{k}$, a ciklus je zatvorena šetnja kod koje su svi vrhovi osim početnog i krajnjeg vrha međusobno različiti. Prema tome, svaki ciklus ima jednako mnogo bridova i vrhova. Graf koji ne sadrži niti jedan ciklus naziva se aciklički graf. Na konkretnom grafu može se istaknuti neku zatvorenu šetnju i neki ciklus kako bi učenici lakše uočili razliku između ta dva pojma. Nadalje, potrebno je objasniti pojam povezanosti koji je iznimno bitan za provedbu radionice. Za graf u Zome sustavu kažemo da ima jednu komponentu povezanosti ako, prolazeći Zome štapićima i Zome lopticama koji čine taj graf, polazeći od proizvoljnog vrha možemo dosegnuti bilo koji drugi vrh tog grafa. Graf je povezan ako se sastoji od jedne komponente povezanosti. Nakon toga slijede primjeri povezanih i nepovezanih grafova za koje učenici trebaju odrediti jesu li povezani ili nisu. Sada se može definirati stablo. Stablo je aciklički graf koji je povezan. Za potrebe daljnjih dokaza nužno je istaknuti da iz definicije stabla slijedi da svako stablo koje sadrži $n$ bridova ima $n+1$ vrhova. Kada se radi o povezanom grafu tvrdnja da graf ima $n$ bridova i $n+1$ vrhova ekivalentna je tvrdnji da je graf aciklički. Tijekom radionice uočit ćemo pomoću Zome materijala ovu činjenicu, što će nam omogućiti da koristimo alternativnu definiciju stabla kao povezanog grafa koji ima $n$ bridova i $n+1$ vrhova. Također se može naglasiti da pri izradi stabla nije bitna boja, duljina i mjere kutova između štapića, već je bitno da stablo ne sadrži cikluse i da je povezan graf.

Kako bi učenici usvojili pojmove ciklus i stablo provode se sljedeće aktivnosti.

Aktivnost 1. Napravite nekoliko stabala.

Učenici nekoliko minuta samostalno izrađuju stabla primjenjujući definiciju stabla. Važno je voditi računa o tome da pravilno primjenjuju 
definiciju grafa, odnosno činjenicu da svaki štapić sadrži dvije Zome loptice. Također je bitno voditi računa o tome da su pravilno primijenili definiciju stabla, tj. činjenicu da je graf povezan i ne sadrži cikluse. Nakon što naprave svoja stabla, može ih se pitati da obrazlože zašto misle da je graf koji su napravili stablo.

Nakon toga slijede primjeri najjednostavnijih stabala. Od učenika se traži da opišu stablo koje nema niti jedan brid. Očekuje se da će učenici zaključiti da je to stablo koje se sastoji od samo jedne Zome loptice. Dakle, ako je broj bridova (štapića) $n=0$, onda stablo sadrži $n+1$ Zome lopticu, odnosno ima jedan vrh. Zatim opisuju stablo za koje je $n=1$. Očekuje se da će zaključiti da je to stablo koje se sastoji od jednog brida i dva vrha koje taj brid sadrži. Nakon toga opisuju stablo za koje je $n=2$, tj. stablo koje sadrži dva brida. Zaključit će da to stablo može izgledati tako da su dva štapića povezana u jednu liniju ili tako da ta dva štapića određuju neki kut čija je mjera različita od $180^{\circ}$.
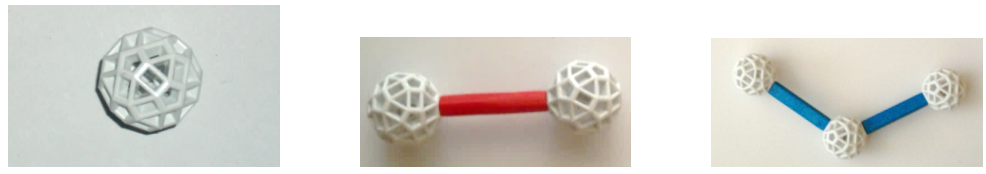

Slika 1: Jednostavna stabla

Nadalje, koristeći PowerPoint prezentaciju učenicima se mogu pokazati neki grafovi i pitati ih jesu li prikazani grafovi stabla. Također, mogu se izraditi neka stabla kao na Slici 2 i pokazati učenicima. Sva tri grafa su povezana i ne sadrže cikluse, što znači da su to stabla. Na prvoj slici je graf u obliku ravne linije koja se sastoji od štapića i Zome loptica. Može se uočiti da graf ima 3 brida i 4 vrha. Na sljedećoj slici je graf u obliku zvijezde. Dobije se tako da se jedna Zome loptica postavi u središte, a svi ostali štapići se postavljaju tako da sadrže središnju Zome lopticu. Graf sadrži 10 bridova i 11 vrhova. Na trećoj slici je graf koji podsjeća na stablo u prirodi, a ima 9 bridova i 10 vrhova, kao i graf na drugoj slici. Može se učiti da prikazana stabla imaju $n$ bridova i $n+1$ vrhova.

Nakon što su učenici analizirali najjednostavnija stabla slijede aktivnosti kojima se želi istaknuti sljedeća tvrdnja: Ako za povezan graf vrijedi da sadrži $n$ bridova i $n+1$ vrhova, onda je takav graf aciklički.

Aktivnost 2. Sastavite graf čiji bridovi čine stranice nekog proizvoljnog mnogokuta. Je li dobiveni graf stablo? Poželjno je učenike podsjetiti na definiciju konveksnog mnogokut: ${ }^{1}$ i napomenuti im da mnogokut, čije

\footnotetext{
${ }^{1}$ Konveksan mnogokut je omeđeni skup u ravnini dobiven kao presjek konačno mnogo poluravnina.
} 

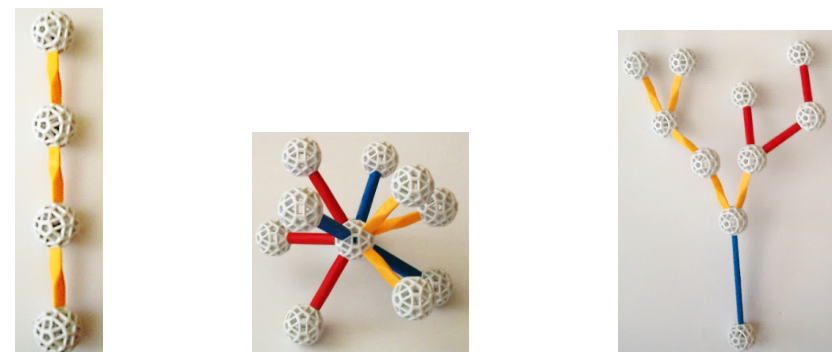

Slika 2: Stabla

stranice su bridovi grafa kojeg trebaju napraviti, ne mora nužno biti konveksan. Prije nego što naprave traženi graf, potrebno im je skrenuti pozornost na to da je mnogokut ravninski lik. Ukoliko ne uspiju izraditi takav graf, može im se pokazati kako se izrađuje graf čiji bridovi čine stranice trokuta, kvadrata, deseterokuta ili peterokuta. Nakon što naprave traženi graf, očekuje se da će zaključiti da je dobiveni graf ciklus. Dakle, dobit će graf za koji vrijedi da je moguće krenuti od bilo koje Zome loptice i prijeći preko cijelog grafa tako da se preko svake Zome loptice prijeđe točno jednom i vrati na početnu Zome lopticu. S obzirom da je stablo aciklički graf, dobiveni graf nije stablo.

Aktivnost 3 . Znamo da stablo ima $n$ bridova i $n+1$ vrhova. Primjenjujući navedeno svojstvo, izradite proizvoljno složenije stablo krenuvši od najjednostavnijeg. Učenici će krenuti od stabla koje se sastoji od samo jedne Zome loptice, a zatim dodavanjem štapića i još jedne Zome loptice izraditi stablo koje se sastoji od jednog štapića koji sa svake strane sadrži Zome lopticu. Nakon toga će ponovno dodati štapić s jednom novom Zome lopticom na jednom kraju i dobiti novo stablo. Uočimo da novi štapić mora sadržavati i jednu novu Zome lopticu, jer bismo u protivnom povezali dva postojeća vrha i dobili novi graf koji nije stablo. Dakle, dodavanjem štapića dobiva se sve složenije stablo pri čemu svako od dobivenih stabala sadrži novi štapić s čije je jedne strane nova Zome loptica koja dodiruje samo taj štapić. Broj vrhova u stablu za jedan je veći od broja bridova. Je li moguće da to vrijedi za povezan graf koji sadrži ciklus? Pretpostavimo da imamo povezan graf napravljen od Zome modela koji ima $n$ bridova i $n+1$ vrhova i koji sadrži ciklus. Uklonimo iz tog ciklusa jedan štapić na način da graf i dalje ostane povezan i ponavljajmo taj postupak sve dok dobiveni povezan graf ne postane stablo, odnosno dok više nema ciklusa. Kako nismo uklonili niti jednu lopticu, dobiveno stablo imalo bi $n+1$ vrhova, što znači da ima $n$ bridova. To nije moguće. Dakle, povezan graf koji ima $n$ bridova i $n+1$ vrhova ne sadrži cikluse, što nam omogućava da stablo definiramo 
kao povezani graf koji ima $n$ bridova i $n+1$ vrhova.

Prije zadavanja sljedeće aktivnosti, poželjno je s učenicima ponoviti pojam konveksnog poliedra ${ }^{2}$ konveksnog pravilnog poliedra ${ }^{3}$ dualnog poliedra te iskazati Eulerov teorem za poliedre.

\begin{tabular}{|c|c|c|c|c|c|}
\hline Poliedar & Zorni prikaz & Oblik strane & $\begin{array}{l}\text { Broj } \\
\text { strana }\end{array}$ & $\begin{array}{l}\text { Broj } \\
\text { bri- } \\
\text { dova }\end{array}$ & $\begin{array}{l}\text { Broj } \\
\text { vrhova }\end{array}$ \\
\hline $\begin{array}{l}\text { Pravilni } \\
\text { tetra- } \\
\text { edar }\end{array}$ & & $\begin{array}{l}\text { jednakostranični } \\
\text { trokut }\end{array}$ & 4 & 6 & 4 \\
\hline $\begin{array}{l}\text { Pravilni } \\
\text { heksa- } \\
\text { edar } \\
\text { (kocka) }\end{array}$ & & kvadrat & 6 & 12 & 8 \\
\hline $\begin{array}{l}\text { Pravilni } \\
\text { oktaedar }\end{array}$ & & $\begin{array}{l}\text { jednakostranični } \\
\text { trokut }\end{array}$ & 8 & 12 & 6 \\
\hline $\begin{array}{l}\text { Pravilni } \\
\text { dodeka- } \\
\text { edar }\end{array}$ & & $\begin{array}{l}\text { pravilni petero- } \\
\text { kut }\end{array}$ & 12 & 30 & 20 \\
\hline $\begin{array}{l}\text { Pravilni } \\
\text { ikosa- }\end{array}$ & & $\begin{array}{l}\text { jednakostranični } \\
\text { trokut }\end{array}$ & 20 & 30 & 12 \\
\hline
\end{tabular}

Tablica 1: Pravilni poliedri

\footnotetext{
${ }^{2}$ Konveksan poliedar je omeđen skup točaka u prostoru dobiven kao presjek konačno mnogo poluprostora.

${ }^{3}$ Konveksan poliedar je pravilan ako su mu sve strane pravilni sukladni mnogokuti, a svaki vrh je krajnja točka jednakog broja bridova. Postoji pet konveksnih pravilnih poliedara. To su pravilni tetraedar, pravilni oktaedar, pravilni heksaedar, pravilni ikosaedar, pravilni dodekaedar.

${ }^{4}$ Dualni poliedar nekog poliedra je poliedar čiji vrhovi su središta strana danog poliedra. Svaki poliedar ima dualni poliedar.
} 
Koristeći prikaz Tablice 1 na slajdu, učenike se podsjeća na pravilne poliedre i njihova svojstva. Osim tablice, treba imati pripremljene modele pravilnih poliedara od Zome materijala kako bi se na konkretnim modelima pokazalo da je svaki poliedar omeden sukladnim pravilnim mnogokutima te da iz svakog vrha izlazi jednak broj bridova.

U Tablici 1 su prikazani pravilni poliedri. Primijetimo da je pravilni tetraedar samodualan, da je dual kocke pravilni oktaedar, a dual ikosaedra pravilni dodekaedar. Vrijede i obrati.

Teorem 1 (Eulerova formula). Za svaki konveksan poliedar vrijedi $V$ $E+F=2$, gdje je $V$ broj njegovih vrhova, $E$ broj bridova, a $F$ broj strana.

Aktivnosti 4 i 5 se izvode kako bi učenici otkrili neka rješenja za stabla koja će koristiti za aktivnosti 6 i 7 . Kako bi se uštedilo na štapićima, nekim grupama se podijele modeli pravilnih ikosaedara, a nekim grupama modeli pravilnih dodekaedara. Nije nužno da svaka grupa provede Aktivnost 4 i Aktivnost 5 jer su zaključci analogni. Pomoću Tablice 1 poželjno je ponoviti da je pravilni ikosaedar geometrijsko tijelo omeđeno s 20 jednakostraničnih trokuta. Ima 30 bridova i 12 vrhova. Uvrštavanjem broja strana, vrhova i bridova u Eulerovu formulu lako se može provjeriti da ta formula vrijedi za pravilni ikosaedar. Zatim se ponovi da je pravilni dodekaedar geometrijsko tijelo omeđeno s 12 pravilnih peterokuta koje ima 30 bridova i 20 vrhova. Također se može provjeriti da Eulerova formula vrijedi za pravilni dodekaedar.

Aktivnost 4. Uklonite bridove zadanog pravilnog ikosaedra tako da preostali bridovi čine stablo. Pritom nije dozvoljeno uklanjati vrhove.

Očekuje se da će učenici zaključiti da iz činjenice da pravilni ikosaedar ima 12 vrhova slijedi da pripadno stablo sadrži 11 bridova, odnosno da je potrebno ukloniti 19 bridova. Postoji više različitih načina na koje se može ukloniti 19 bridova, a da preostali bridovi čine stablo. Jedno moguće rješenje je prikazano na Slici 3 .

Aktivnost 5. Uklonite bridove zadanog pravilnog dodekaedra tako da preostali bridovi čine stablo. Pritom nije dozvoljeno uklanjati vrhove.

Analogno kao i u prethodnom slučaju očekuje se da će učenici zaključiti da iz činjenice da pravilni dodekaedar ima 20 vrhova slijedi da pripadno stablo sadrži 19 bridova, odnosno da je potrebno ukloniti 11 bridova. Kao i u u slučaju ikosaedra zaključuju da postoji više različitih načina na koje se može ukloniti 11 bridova. Dakle, moguće je dobiti više različitih stabala. Jedno moguće rješenje je prikazano na Slici 4 .

Učenicima se podijele gotovi modeli koji prikazuju središte ikosaedra i njegovog duala dodekaedra iz kojega izlazi 20 žutih štapića duljine $y_{2}$ i 12 crvenih štapića duljine $r_{2}$, pri čemu je raspored 20 žutih i 12 crvenih štapića dobiven tako da je u svaku trokutastu i svaku peterokutnu rupu 


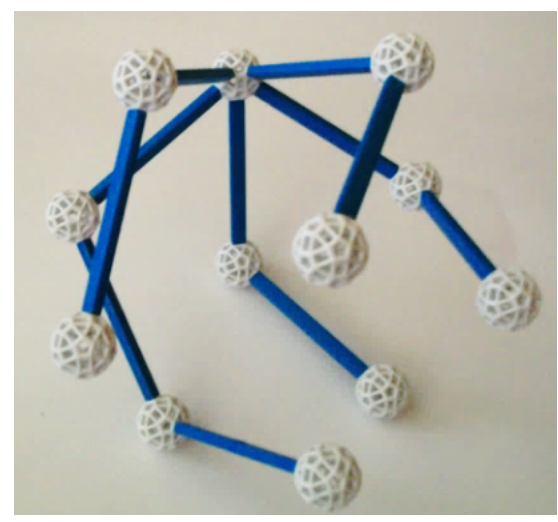

Slika 3: Stablo ikosaedra

na Zome loptici postavljen žuti, odnosno crveni štapić. Dakle, jedino pravokutne rupe trebaju ostati nepopunjene. Zatim se na svaki crveni i svaki žuti štapić postavi Zome loptica.

Zome loptice nad crvenim štapićima moguće je povezati pomoću 30 plavih štapića duljine $b_{2}$. Tih 30 plavih štapića duljine $b_{2}$ čini pravilni ikosaedar. Analogno, Zome loptice nad žutim štapićima moguće je povezati pomoću 30 plavih štapića duljine $b_{1}$. Tih 30 plavih štapića duljine $b_{1}$ čini pravilni dodekaedar.

Grupama učenika koji su rješavali Aktivnost 4 podijeli se Aktivnost 6, a grupama koji su rješavali Aktivnost 5 podijeli se Aktivnost 7.

Aktivnost 6. Na modelu izradite stablo koje sadrži vrhove pravilnog ikosaedra pomoću štapića duljine $b_{2}$, a nakon toga spojite žute štapiće pomoću plavih štapića duljine $b_{1}$ tako da se nikoja dva plava štapića ne presijecaju.

Učenicima je dozvoljeno korištenje stabla koje su dobili u Aktivnosti 4 kao predložak. Poželjno je, pomoću PowerPoint prezentacije, pokazati što učenici moraju izraditi (Slika 6).

Samostalno izrađuju stablo koje sadrži vrhove ikosaedra, a zatim spajaju žute štapiće pomoću plavih štapića duljine $b_{1}$. Očekuje se da će uočiti da će tim spajanjem dobiti neki graf sastavljen od 19 plavih štapića duljine $b_{1}$. Zatim se postavlja pitanje čini li tih 19 štapića stablo koje sadrži vrhove dodekaedra, odnosno je li dobiveni graf povezan i sadrži li cikluse. Najprije se može provjeriti je li svih 20 središta strana ikosaedra (vrhova dodekaedra) povezano nekim štapićem duljine $b_{1}$. Graf kojeg čine 11 plavih štapića duljine $b_{2}$ (dobiven u Aktivnosti 4) je stablo pa je povezan i ne sadrži cikluse. Iz toga slijedi da ne sadrži barem jedan brid svake strane ikosaedra pa je sada svako središte strane ikosaedra 


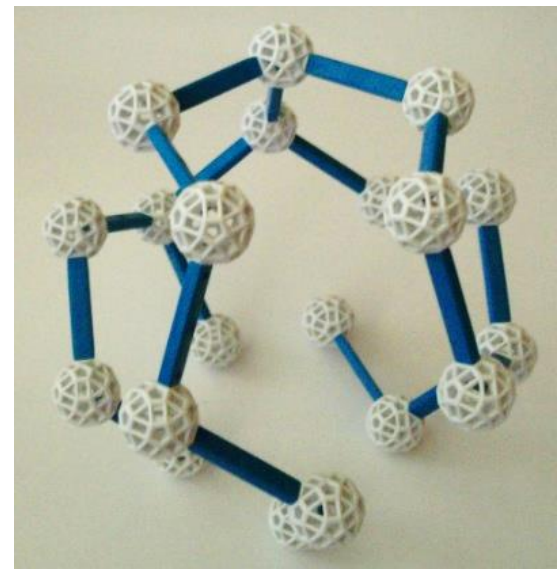

Slika 4: Stablo dodekaedra

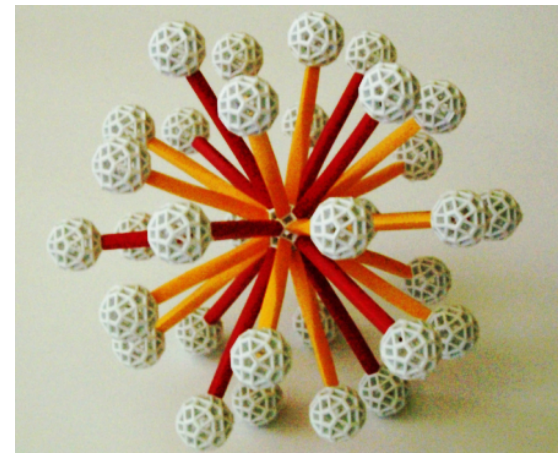

Slika 5: Model za izradu stabala

povezano plavim štapićem duljine $b_{1}$ s nekim drugim središtem strane ikosaedra. Dobiveni graf koji se sastoji od 19 plavih štapića duljine $b_{1}$ je povezan jer stablo koje se sastoji od štapića duljine $b_{2}$ (Aktivnost 4) ne sadrži cikluse. Nadalje, svaki vrh ikosaedra je povezan plavim štapićem duljine $b_{2}$, a kako se nikoja dva plava štapića ne smiju presijecati, onda vrijedi da ne postoji ciklus sastavljen od štapića duljine $b_{1}$. Ako bi postojao takav ciklus, onda bi to značilo da neki vrh ikosaedra nije povezan štapićem duljine $b_{2}$. Dakle, graf koji se sastoji od 19 plavih štapića duljine $b_{1}$ ne sadrži cikluse. Kako je dobiveni graf povezan i ne sadrži cikluse, onda slijedi da je dobiveni graf stablo. Dakle, time su dobivena dva stabla koja se međusobno isprepliću.

Učenicima koji su rješavali Aktivnost 5 zadaje se Aktivnost 7. Način 


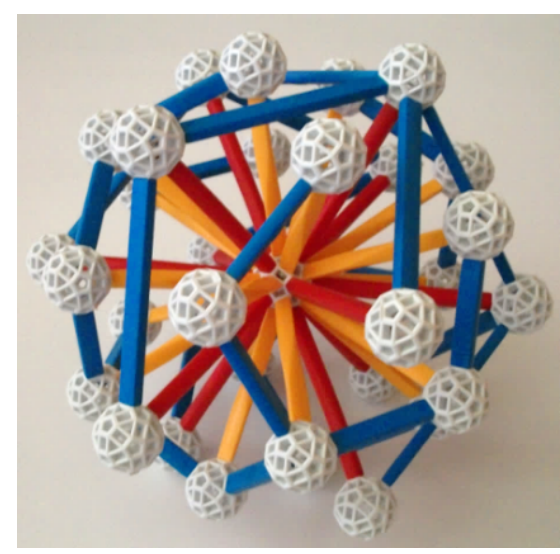

Slika 6: Isprepletena stabla dodekaedra i ikosaedra

zaključivanja u potpunosti je analogan onome opisanom u Aktivnosti 6 pa ga ovdje nećemo navoditi.

Aktivnost 7. Na modelu izradite stablo koje sadrži vrhove pravilnog dodekaedra pomoću štapića duljine $b_{1}$, a nakon toga spojite crvene štapiće pomoću plavih štapića duljine $b_{2}$ tako da se nikoja dva plava štapića ne presijecaju.

Koristeći dva izrađena stabla (aktivnosti 6 i 7) može se dokazati da Eulerova formula vrijedi za pravilni ikosaedar i dodekaedar. Znamo da niti jedan vrh nije uklonjen i da je ukupan broj bridova u stablima 30 pa vrijedi da je ukupan broj bridova u stablima jednak ukupnom broju bridova u svakom od ta dva poliedra; ikosaedru i dodekaedru. Neka je $V_{I}$ broj vrhova stabla ikosaedra, a $E_{I}$ broj bridova stabla koje se dobije uklanjanjem bridova ikosaedra. Tada iz definicije stabla slijedi da je $V_{I}=E_{I}+1$. U tom trenutku potrebno je napomenuti važnost dokazivanja da je graf koji je dobiven spajanjem vrhova dodekaedra pomoću plavih štapića duljine $b_{1}$ stablo. Kako je dobiveni graf stablo, onda vrijedi da je ukupan broj bridova tog grafa za jedan veći od ukupnog broja vrhova tog grafa. Analogno, neka je $V_{D}$ broj vrhova stabla dodekaedra, a $E_{D}$ broj bridova stabla koje se dobije uklanjanjem bridova dodekaedra. Tada iz definicije stabla slijedi da je $V_{D}=E_{D}+1$. Zbrajanjem tih dviju jednakosti dobije se da je $V_{I}+V_{D}=E_{I}+E_{D}+2$. Sada, korištenjem svojstva dualnosti, zaključujemo da je broj vrhova dodekaedra jednak broju strana ikosaedra, jer je središte svake strane ikosaedra vrh dodekaedra. Ako broj strana ikosaedra označimo s F, onda vrijedi $F=V_{D}$. Također znamo da je ukupan broj bridova ikosaedra jednak 30 i vrijedi da je $E_{I}+E_{D}=30$. Ako broj bridova ikosaedra označimo s $E$, onda je $E_{I}+E_{D}=E$. Sada broj vrhova ikosaedra možemo označiti s $V$ i 
znamo da je broj vrhova ikosaedra jednak broju vrhova stabla ikosaedra pa vrijedi da je $V+F=E+2$, tj. vrijedi da je $V-E+F=2$. Time je dokazano da Eulerov teorem vrijedi za pravilni ikosaedar i njegov dual pravilni dodekaedar. Analogno bi se moglo pokazati da Eulerov teorem vrijedi za poliedre koristeći bilo koji poliedar i njegov dual.

Aktivnost 8. Koristeći Schlegelov dijagram nekog poliedra pokaži da vrijedi Eulerova formula.

Aktivnost 8 učenici neće izvoditi samostalno. Na samom početku potrebno je objasniti što je Schlegelov dijagram, a zatim nacrtati Schlegelov dijagram $5^{5}$ nekog poliedra, primjerice, kocke i označiti bojom središte svake strane kocke. Ta središta su vrhovi duala kocke, tj. oktaedra. Nakon toga je potrebno istaknuti stablo koje sadrži vrhove kocke i stablo koje sadrži vrhove oktaedra. Stabla se označe tako da se najprije odaberu bridovi stabla kocke, a zatim se odaberu bridovi stabla oktaedra tako da ne presijecaju bridove stabla kocke. Dakle, povežu se središta strana kocke s one strane s koje je brid uklonjen. Prebrojavanjem se može utvrditi da je zbroj broja bridova u tim stablima jednak 12, odnosno da je jednak ukupnom broju bridova u svakom od navedenih poliedara. Ako se broj bridova kocke označi sa $E$, a sa $E_{O}$ broj bridova stabla oktaedra i sa $E_{K}$ broj bridova stabla kocke, onda vrijedi da je $E=E_{O}+E_{K}$. $\mathrm{Na}$ Schlegelovom dijagramu označena su dva stabla pa analogno kao u prethodnom slučaju vrijedi jednakost $V_{O}+V_{K}=E_{K}+E_{O}+2$, pri čemu je $V_{O}$ broj vrhova stabla oktaedra, a $V_{K}$ broj vrhova stabla kocke.

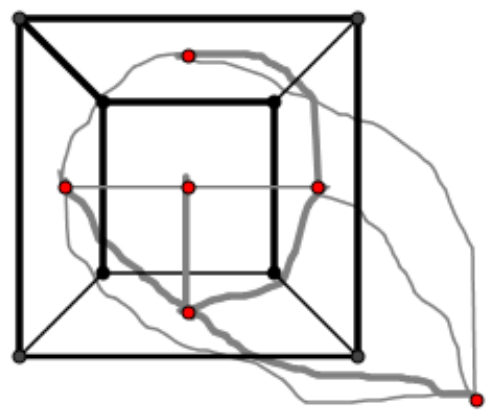

Slika 7: Schlegelov dijagram

Nadalje, kako je pravilni oktaedar dual kocke onda vrijedi da je broj strana kocke jednak broju vrhova oktaedra. Dakle, ako se broj strana

\footnotetext{
${ }^{5}$ Schlegelovi dijagrami su ravninski grafovi (grafovi koji se mogu prikazati u ravnini bez presijecanja bridova) poliedara; pri čemu vrhovi i bridovi grafa odgovaraju vrhovima i bridovima poliedara.
} 
kocke označi sa $F$, onda vrijedi da je $F=V_{O}$. Označavanjem broja vrhova kocke sa $\mathrm{V}$ i uvrštavanjem slijedi da je $V+F=E+2$, tj. $V-E+F=2$. Time je, koristeći stabla koja se isprepliću i Schlegelov dijagram, pokazano da Eulerov teorem vrijedi za kocku i njezin dual pravilni oktaedar.

Aktivnost se može provesti i tako da se krene od već izrađene kocke i njezinog duala pravilnog oktaedra. Nasumično se uklone bridovi kocke tako da preostali bridovi čine stablo. Ako je neki brid kocke dio stabla, onda se ukloni brid oktaedra koji presijeca taj brid kocke. Na taj način se dobije stablo oktaedra. Kako postoji 5 točaka u kojima se presijecaju brid kocke i brid oktaedra, slijedi da dobivena stabla sadržavaju ukupno $7+5=12$ bridova. Analogno, kao i u slučaju ikosaedra i dodekaedra, dokaže se da vrijedi Eulerova formula.
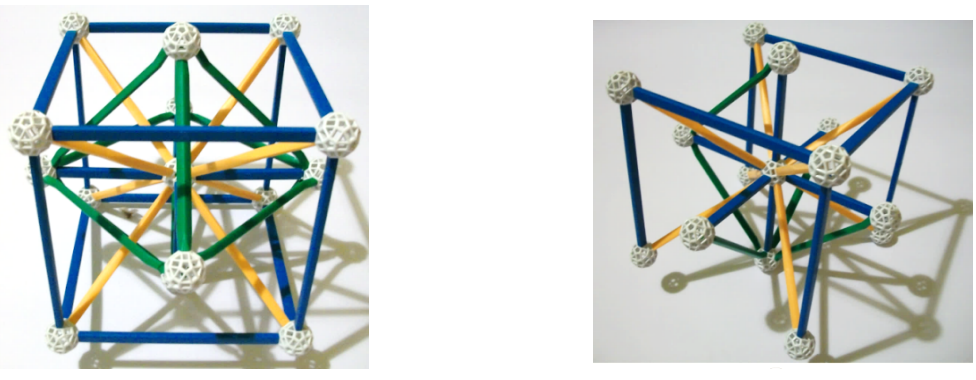

Slika 8: Kocka i pravilni oktaedar. Isprepletena stabla kocke i oktaedra

Dokaz Eulerove formule se može provesti na isti način za pravilni tetraedar i njegov dual koristeći Schlegelov dijagram tetraedra ili model tetraedra i duala.

\section{Napomene o izvođenju radionice}

Opisana radionica je izvedena u 2. razredu srednje škole hotelijerskoturističkog usmjerenja. Umjesto zaključka dajemo napomene proizašle iz iskustva izvođenja radionice.

- Poželjno je da se unaprijed pripreme modeli pravilnih poliedara različitih veličina kako bi se zornije prikazala dualnost.

- Može se svakoj grupi podijeliti prazna Tablica 1 s popisom pravilnih poliedara i zahtijevati od učenika da samostalno prebroje vrhove, bridove i strane, a zatim zaključe o njihovoj vezi. Nakon što prebroje vrhove, bridove i strane pravilnih poliedara, učenici trebaju uočiti da vrijedi da je $V-E+F=2$. Na taj će način učenici samostalno otkriti Eulerovu formulu za pravilne poliedre, pri čemu treba naglasiti da ta formula vrijedi za bilo koji konveksan poliedar. 
- Kako se učenici ne susreću s pojmom stabla na nastavi, treba ih podsjećati na definiciju stabla tijekom cijele radionice. Potrebno je konstantno naglašavati zašto je pojam stabla bitan za dokaz tvrdnje, a posebno u dijelu u kojem se objašnjava da su dobivena dva isprepletena stabla. Poželjno je, tijekom dokazivanja, često se vraćati nekoliko koraka unatrag i ponavljati objašnjenje kako bi učenici mogli pratiti, povezivati dobivene rezultate i na kraju razumjeti zaključak.

- Tijekom izvođenja radionice uočeno je da je učenicima bilo potrebno ponoviti definiciju dualnih poliedara u trenutku kad je trebalo zaključiti da je broj strana ikosaedra jednak broju vrhova dodekaedra. Također je važno konstantno naglašavati da se stablo ikosaedra i stablo dodekaedra dobiju uklanjanjem bridova i da pritom nije dozvoljeno ukloniti niti jedan vrh. Većina učenika nije odmah zaključila da je zbroj broja bridova stabla ikosaedra i stabla dodekaedra jednak broju bridova ikosaedra, odnosno dodekaedra. Da bi lakše došli do zaključka, može se na ploči istaknuti broj vrhova, bridova i strana ikosaedra i dodekaedra te broj vrhova i bridova stabla ikosaedra i stabla dodekaedra.

- Velik broj definicija učenicima je otežavao praćenje. Preporučujemo da se definicije koje se koriste na satu ponove na nekim od prethodnih satova, a na radionici se onda mogu istaknuti samo obje definicije stabla i dualnih poliedara. Ukoliko bi se radionica izvodila u trajanju od 45 minuta, onda je dovoljno provesti aktivnosti 4 i 6 te 5 i 7.

- Aktivnost 8 nije predviđena za radionicu koja se izvodi u trajanju od dva školska sata i nije nužna prilikom izvođenja radionice. Navedena je kao poopćenje dokaza za bilo koji poliedar.

- Ukoliko bi se Aktivnost 8 izvela koristeći modele kocaka i njihovih duala oktaedara, onda treba unaprijed izraditi te modele i podijeliti ih svakoj grupi. Da bi se izradio navedeni model, potrebno je najprije napraviti kocku duljine brida $b_{3}$. Zatim treba odrediti središte te kocke i svaki vrh kocke povezati sa središtem pomoću štapića duljine $y_{3}$. Dakle, potrebno je odrediti središte kocke kako bi se mogao izgraditi pravilni oktaedar i kako bi kocka i njezin dual pravilni oktaedar bili povezani kao jedan model. Iz središta kocke se postavi 6 plavih štapića duljine $b_{2}$ tako da budu usmjereni prema središtu svake strane kocke. Nad tim plavim štapićima izgradi se pravilni oktaedar. 


\section{Literatura}

[1] A. Brozović, Primjena Zome Tool modela u nastavi matematike, diplomski rad, Sveučilište u Rijeci Odjel za matematiku, 2017.

[2] A. Brozović, S. Rukavina, Zome Tool modeli, Matematika i škola, 92 (2017); 51-54

[3] G. W. Hart, H. Piccioto, Zome Geometry Hands-on Learning with Zome Models, Key Curriculum Press, 2001.

[4] https://en.wikipedia.org/wiki/Zome

[5] http://www.zometool.com

[6] http://www.zometool.com/content/

lessonplan2002-2010edition.pdf

Anita Brozović

V. gimnazija, Zagreb

E-mail adresa: abrozovic24@gmail.com

Sanja Rukavina

Odjel za matematiku, Sveučilište u Rijeci

E-mail adresa: sanjar@math.uniri.hr 